\title{
Performance and Empirical Analysis of Photovoltaic Modules Made of Different Technologies Using Capacity Evaluation Method
}

\author{
Matej ŽNIDAREC, Damir ŠLJIVAC, Dario DOŠEN
}

\begin{abstract}
Performance of 5 photovoltaic (PV) modules made of different technologies (monocrystalline silicon, polycrystalline silicon, amorphous silicon, copper indium selenide and heterojunction with intrinsic layer) is evaluated according to the short-term capacity evaluation method described in IEC TS 61724-2 standard. Measurements for the analysis are obtained from the data acquisition system developed by the Laboratory for Renewable Energy Sources at the Faculty of Electrical Engineering, Computer Science and Information Technology (FERIT) Osijek which is described in the paper. Results of the performance analysis according to the IEC TS 61724-2 standard indicate that the copper indium selenide PV module Solar Frontier SF150-S has the greatest performance, therefore it is the most suitable PV module for the micro-location of Osijek, Croatia with European humid continental climate. The lowest performance of all studied PV modules is achieved by polycrystalline silicon PV module Bisol BMU 250. Empirical analysis of the relations of various electrical and meteorological parameters is performed and dependencies are evaluated. In the last section, mathematical models of PV module efficiency in relation to the module temperature are derived based on empirical analysis of measurements.
\end{abstract}

Keywords: capacity evaluation method; empirical analysis; performance analysis; photovoltaic module

\section{INTRODUCTION}

Exploitation of renewable energy sources (RES) has grown rapidly in the $21^{\text {st }}$ century. This is the result of frameworks and policies which subsidize and encourage usage of RES for electricity production. Many international agreements on greenhouse emissions reduction are signed (Kyoto, Cancun, Lima, Paris) leading to global sustainable energy concept. The most recent framework which the European Union adopted is 2030 Climate and Energy Policy Framework. The framework targets $30 \%$ cut in greenhouse gas emissions compared to 1990 levels, at least a $27 \%$ share of renewable energy consumption and at least $27 \%$ energy savings compared to the business-as-usual scenario [1]. PVs are a key technology for decarbonized energy supply shift according to [2]. In 2017, additional $99 \mathrm{GW}$ of PV are installed globally leading to total capacity of $402 \mathrm{GW}$ [3].

Many papers conducted long-term analysis of the performance of different technology PV modules and systems in various locations. These papers conducted an analysis of the PV performance based on one-year or longer measurements. In [4]-[11], performance analysis of different PV technologies based on one-year measurements is done, while in [12-22] analysis is conducted based on over one year of measurements. All these papers use long-term energy evaluation method for analysis described either in withdrawn IEC 61724:1998 standard or new IEC TS 61724-3:2016 standard, depending on the year of publication. Main parameter which reflects the $\mathrm{PV}$ performance is the performance ratio defined as an electricity generation of a PV system relative to the expected power production for a specified set of conditions [23]. Results indicated that performance of the PV depends on various factors such as solar irradiance, solar spectrum, temperature, wind speed, humidity, PV technology type, dust deposition and shading.

This paper, however, studied the performance of $5 \mathrm{PV}$ modules made of different technologies installed on the roof of the FERIT Osijek building using the short-term capacity evaluation method prescribed by the IEC TS 61724-2 standard [24] published in 2016. Osijek is placed in the eastern part of Croatia with European humid continental climate [25]. The Studied PV modules and PV technologies they are made of are the following: monocrystalline silicon (m-Si)Bisol BMO 250, polycrystalline silicon (p-Si)Bisol BMU 250, amorphous silicon (a-Si)Masdar MPV100-S, copper indium selenide(CIS) Solar Frontier SF150-S and heterojunction with intrinsic layer (HIT) Panasonic VBHN240SE10. Experimental data acquisition system for measurements, which complies to the IEC TS 61724-1 measurement standard [26], is developed by the Laboratory for Renewable Energy Sources [27], and described in section 2 along with the PV modules which are examined, and capacity evaluation method (IEC TS 61724-2 [24]) which is used for the performance analysis. Results of the capacity evaluation method are given in section 3 followed by empirical evaluation of the results in which mathematical models of PV module efficiency in dependence to the module temperature are also derived.

Novelty of this paper lays in new knowledge gained about performance of PV modules made of different technologies for European humid-continental climate in Osijek, Croatia. Furthermore, mathematical models of efficiency for different PV modules based on short-term analysis are derived.

\section{METHODOLOGY \\ 2.1 Experimental System for Measurements}

In order to analyse the performance of the PV modules made of different technologies, same outdoor conditions must take place for each PV module while simultaneously and continuously electrical and climate parameters are recorded in real time. Measurement data acquisition system, which is developed by Laboratory for Renewable Energy Sources at the FERIT Osijek, given in Fig. 1, records PV module output DC voltage and current, module temperature, ambient temperature, air humidity, wind speed and solar irradiance. Furthermore, measured data is stored in a local and cloud database for further analysis [27]. 


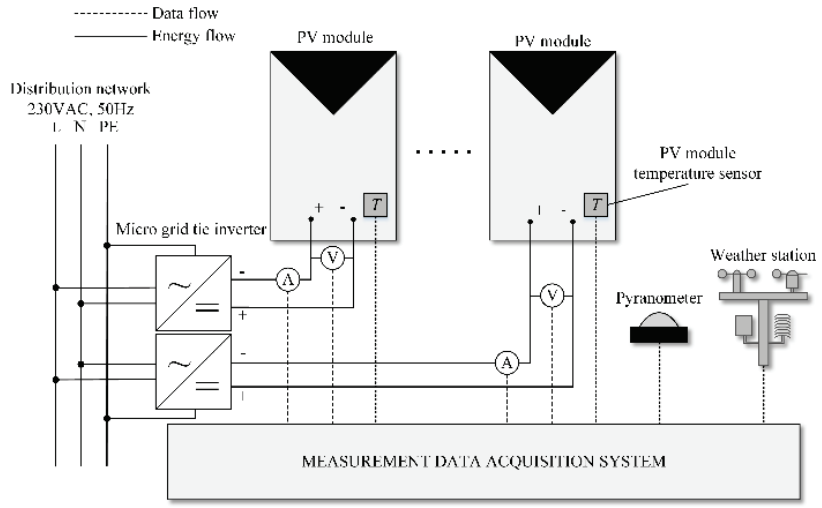

Figure 1 Measurement data acquisition system scheme

Every PV module is connected to the micro grid-tie inverter (Fig. 2). Every inverter has integrated a maximum power point (MPP) tracker which extracts maximum DC power from the PV module. This measurement system does not consider inverter efficiency (electrical measurements are recorded on the DC side of the inverter), therefore this paper studies only PV module performance.

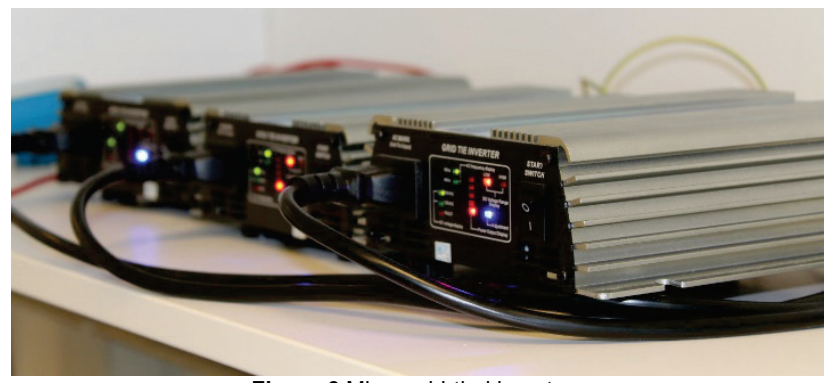

Figure 2 Micro grid-tied inverters

System measures and stores output from 5 different PV modules: m-SiBisol BMO 250, p-SiBisol BMU 250, aSiMasdar MPV100-S, CIS Solar Frontier SF150-S and HIT Panasonic VBHN240SE10. Technical characteristics of examined PV modules are given in Tab. 1 where electrical parameters apply for standard test conditions (STC)[28]-[32].

\subsection{Capacity Evaluation Method}

Capacity evaluation method according to IEC TS 61724-2 standard describes a procedure for measuring and analysing the power production of a PV system. Goal of this procedure is to evaluate quality of the PV system performance. Standard recommends that test includes data from two to seven days of stable data. Test may be completed in any time of year. The weather is characterized by plane of array (POA) solar irradiance (e.g. global solar irradiance in case of flat plate systems), ambient temperature and wind speed [24]. Authors chose measurements from October 2017 for the analysis in order to evaluate the performance of $5 \mathrm{PV}$ modules made of different technologies during the autumn meteorological conditions. Each measuring point (electrical and meteorological) represents 1-minute average.

\subsubsection{Procedure}

The standard distinguishes constrained and an unconstrained operation mode of the plant. Constrained operation of the plant is a condition when all inverters are limited by the capability of the inverters (saturated) rather than by the output from the PV array. Unconstrained operation of a plant is a condition when outputs of all inverters freely follow PV array response to the solar insolation rather than being limited by the inverter capability [24].

The standard defines target reference conditions (TRC) for unconstrained operation. TRC are the conditions which are defined for the performance target of the PV module. TRC should be chosen so the unconstrained operation is accomplished. Furthermore, the TRC should reflect an ambient temperature and wind speed that are frequently observed at the site and the highest solar irradiance that is unlikely to cause constrained operation for the lowest temperature expected to be included in the test [24]. TRC used in this research for capacity evaluation of 5 PV modules made of different technologies are given in Tab. 2 and reflect STC.

Table 1 Technical characteristics of studied PV modules [28]-[32]

\begin{tabular}{|c|c|c|c|c|c|}
\hline Parameter & $\begin{array}{c}\text { Bisol } \\
\text { BMO 250 }\end{array}$ & $\begin{array}{c}\text { Bisol } \\
\text { BMU 250 }\end{array}$ & $\begin{array}{c}\text { Masdar } \\
\text { MPV100-S }\end{array}$ & $\begin{array}{c}\text { Solar Frontier } \\
\text { SF150-S }\end{array}$ & $\begin{array}{c}\text { Panasonic } \\
\text { VBHN240SE10 }\end{array}$ \\
\hline PV technology & $\mathrm{m}-\mathrm{Si}$ & $\mathrm{p}-\mathrm{Si}$ & $\mathrm{a}-\mathrm{Si}$ & CIS & HIT \\
\hline MPP power / W & 250 & 250 & 100 & 150 & 240 \\
\hline MPPvoltage/ V & 30,5 & 30,3 & 76 & 81,5 & 43,7 \\
\hline MPP current / A & 8,2 & 8,25 & 1,33 & 1,85 & 5,51 \\
\hline Module efficiency / \% & 15,3 & 15,3 & 7 & 12,2 & 19 \\
\hline Open-circuit voltage / V & 37,9 & 38,4 & 100 & 108 & 52,4 \\
\hline Short-circuit current / A & 8,8 & 8,75 & 1,57 & 2,2 & 5,85 \\
\hline NOCT $/{ }^{\circ} \mathrm{C}$ & 44 & 44 & $\mathrm{n} / \mathrm{a}$ & 47 & 44 \\
\hline Power temperature coefficient $/ \% /{ }^{\circ} \mathrm{C}$ & $-0,35$ & $-0,4$ & $-0,2$ & $-0,31$ & $-0,3$ \\
\hline Voltage temperature coefficient $/ \% /{ }^{\circ} \mathrm{C}$ & $-0,35$ & $-0,32$ & $-0,3$ & $-0,3$ & $-0,25$ \\
\hline Current temperature coefficient $/ \% /{ }^{\circ} \mathrm{C}$ & $+0,05$ & $+0,06$ & $+0,1$ & $+0,01$ & $-0,03$ \\
\hline PV module area $/ \mathrm{m}^{2}$ & 1,63 & 1,63 & 1,43 & 1,23 & 1,26 \\
\hline
\end{tabular}

Table 2 Target reference conditions (TRC) used for the performance analysis

\begin{tabular}{|l|c|}
\hline \multicolumn{1}{|c|}{ Parameter } & Value \\
\hline Solar irradiance $G_{\mathrm{TRC}} / \mathrm{W} / \mathrm{m}^{2}$ & 1000 \\
\hline Module temperature $t_{\mathrm{TRC}} /{ }^{\circ} \mathrm{C}$ & 25 \\
\hline Wind speed $w_{\mathrm{TRC}} / \mathrm{m} / \mathrm{s}$ & 1 \\
\hline
\end{tabular}

Each data stream collected via measurement data acquisition system is validated and filtered according to the IEC TS 61724-2 standard. Minimum solar irradiance (550
$\mathrm{W} / \mathrm{m}^{2}$ ) and minimum number of 15 -minutes average data points (40) for corresponding season (autumn) are also used according to the standard.

Adjustment of the measured output power of the PV module to the targeted performance for the TRC is done by correction factor for each measurement point. Correction factor is calculated as in (1) [24]. 
$C F_{i}=\frac{P_{\text {pred targ }, i}}{P_{\text {pred meas }, i}}$

where: $C F_{i}$ - correction factor for the $i^{\text {th }}$ minute, $P_{\text {pred targ }, i}-$ predicted output power of the module at the TRC for the $i^{\text {th }}$ minute, $P_{\text {pred meas }, i}$ - predicted output power of the module at the measured meteorological conditions for the $i^{\text {th }}$ minute.

Predicted output powers needed for determining of the correction factor $C F_{i}$ are calculated with the output power mathematical model presented in section 2.2.2. After the calculation of correction factor, output power measured by measurement data acquisition system is then corrected by the correction factor for all points measured during unconstrained stable operation, as in (2) [24]:

$P_{\text {corr }, i}=P_{\text {meas }, i} \cdot C F_{i}$

where: $P_{\text {corr }, i}-$ corrected output power of the PV module for the $i^{\text {th }}$ minute, $P_{\text {meas }, i}-$ measured output power of the PV module for the $i^{\text {th }}$ minute.

After the correction, measured corrected power and performance targeted output at the TRC can be compared using one of the four possible performance indices. Authors have chosen the ratio called performance index for power, PIP (\%) as in (3) [24], with target output power at the TRC equal to nominal output power of the PV module at the STC (Tab. 2).

$P I P=\sum_{i=1}^{n} \frac{P_{\text {corr }, i}}{P_{\text {target }, i}} \cdot 100$

where: $P I P$ - performance index for power, $P_{\text {target }, i}$ targeted output power of the PV module at the TRC for the $i^{\text {th }}$ minute, $n$ - total number of minutes in the observed period.

\subsubsection{Mathematical Model of PV Module Output Power}

Mathematical model for PV module output power calculation is given in (4) [24]:

$P_{\mathrm{pr}, i}=P_{\mathrm{TRC}} \cdot \frac{G_{\mathrm{meas}, i}}{G_{\mathrm{TRC}}} \cdot\left(1+\gamma \cdot\left(t_{\mathrm{mod}, i}-t_{\mathrm{TRC}}\right)\right)$

where: $P_{\mathrm{pr}, i}-$ predicted output power of the module for the $i^{\text {th }}$ minute, $P_{\mathrm{TRC}}-$ output power of the module at the TRC, $G_{\text {meas }, i}-$ measured solar irradiance for the $i^{\text {th }}$ minute, $G_{\mathrm{TRC}}$ - solar irradiance used to target output power at the TRC, $\gamma$ - power temperature coefficient of PV module, $t_{\bmod , i}$ measured module temperature for the $i^{\text {th }}$ minute, $t_{\mathrm{TRC}}-$ module temperature at the TRC.

Since this paper evaluates only PV modules (not PV power plants), output power of the PV module is considered to be linear with the solar irradiance. Using the mathematical model given in (4), output power of the PV module depends on solar irradiance and module temperature. Due to small and irrelevant wind speeds that are measured on the test site, PV module's output power dependence on wind speed is neglected in the mathematical model. $P_{\text {TRC }}$ and $\gamma$ for each PV module are obtained from manufacturers datasheet.

\section{ANALYSIS RESULTS}

3.1 Performance Analysis of 5 PV Modules Made of Different Technologies Using Capacity Evaluation Method According to IEC TS 61724-2 Standard

Capacity evaluation method of 5 PV modules made of different technologies is done for 5 relatively sunny days during October 2017. Solar irradiance of 5 relatively sunny days for which the capacity evaluation method is performed is given in Fig. 3.

Averaged performance index for power of each PV module studied is given in Tab. 3. Results show that $\mathrm{p}-\mathrm{Si}$ PV module Bisol BMU 250 achieves the lowest while the CIS PV module Solar Frontier SF150-S achieves the highest performance index for power. Solar Frontier SF $150-S$ performance index for power is over $100 \%$ which means its performance is better than predicted by the mathematical model. Although a-Si PV module Masdar MPV100-S has the lowest conversion efficiency, its performance index is better than $\mathrm{m}$-SiBisol BMO 250, $\mathrm{p}$ SiBisol BMU 250 and HIT Panasonic VBHN240SE10 PV module.

In order to evaluate the performance index for power obtained using the IEC TS 61724-2 standard, empirical evaluation of performance analysis of studied PV modules for observed period is given in section3.2.

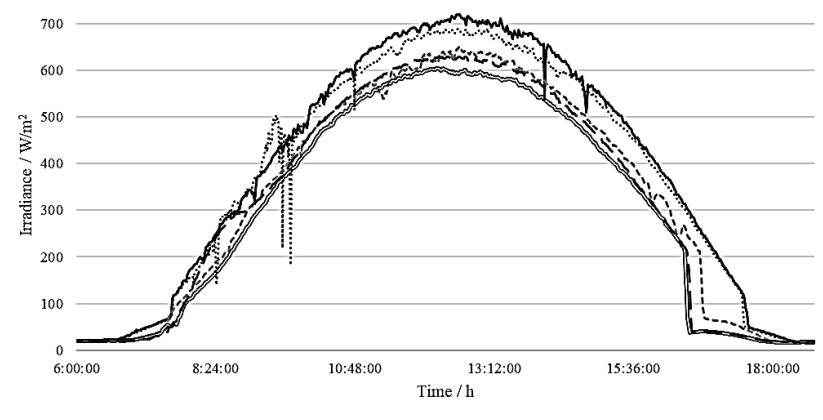
Figure 3 Solar irradiance of 5 days in October 2017 used for the performance analysis

Table 3 Averaged performance index for power $(P I P)$ of studied PV modules

\begin{tabular}{|l|c|}
\hline \multicolumn{1}{|c|}{ PV module } & $P I P / \%$ \\
\hline Bisol BMO 250 & 86,63 \\
\hline Bisol BMU 250 & 75,7 \\
\hline Masdar MPV100-S & 90,06 \\
\hline Solar Frontier SF150-S & 102,77 \\
\hline Panasonic VBHN240SE10 & 83,64 \\
\hline
\end{tabular}

\subsection{Empirical Evaluation of Performance Analysis of 5 PV Modules Made of Different Technologies in the} Observed Period

Empirical analysis of the PV modules in this section is done for the data filtered according to the IEC TS 61724-2 standard. Fig. 4 shows the relation of the module temperature and solar irradiance while Fig. 5 shows the relation of ambient temperature and module temperature. It is visible in Fig. 4 that module temperature exhibits, in general, proportional dependency on solar irradiance but it is also influenced by duration of previous cumulative 
exposure to the Sun radiation (irradiation) and different ambient temperatures, which therefore results in the different module temperatures even at the same solar irradiances [33].

Fig. 6 presents the influence of solar irradiance on MPP current. MPP current is normalized to the PV module MPP current at the STC. Results show linear dependency of the MPP current to the solar irradiance which is visible from the linear trend curves plotted in the figure. Accuracy of the linear dependency assumption is confirmed with strong coefficients of determination $\left(R^{2}\right)$ of the trend curves which are given in Tab. 4. Results of $R^{2}$ given in Tab. 4 indicate that HIT PV module Panasonic VBHN240SE10 has the most accurate linear regression curve that confirms linear dependency of MPP current and solar irradiance $(98,08 \%)$.

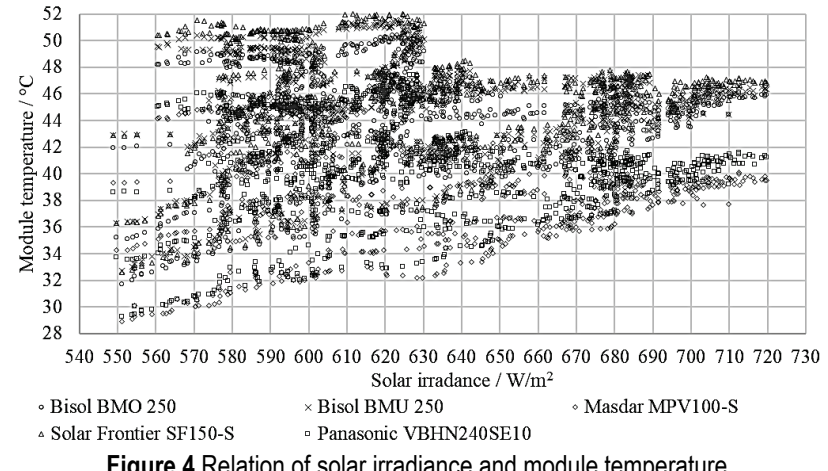

Figure 4 Relation of solar irradiance and module temperature

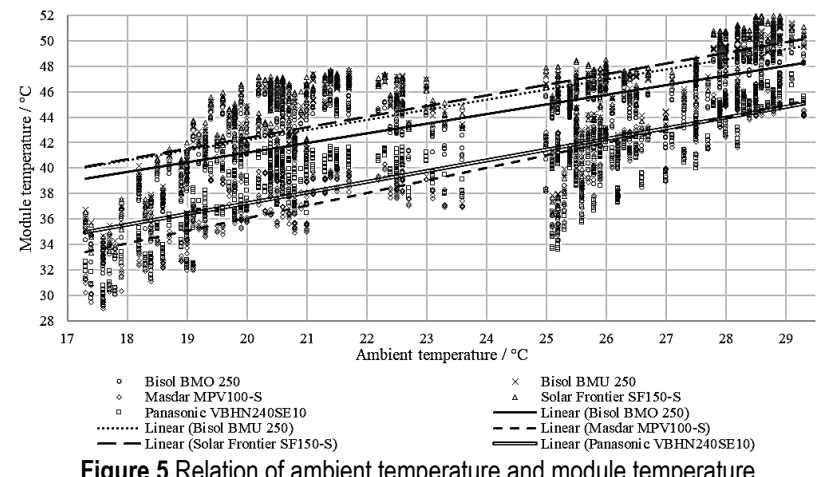

This $R^{2}$ value can also relate to the shape of the PV module $I-V$ curve. It is generally known from the literature that short-current current of an ideal PV cell is equal to MPP current i.e. shunt resistance is infinite while series resistance is zero [34]. By observing the $I-V$ curves given in manufacturers datasheet of the studied PV modules, it is visible that the $R^{2}$ value matches the slope of each PV module's $I-V$ curve if the operating point moves from short-circuit to the MPP [28]-[32]. If the slope is zero, short-circuit current is equal to MPP current (no losses). The bigger the slope of the characteristic, the further from ideal the PV module. HIT PV module has no slope at all while the $\mathrm{m}$-Si has the biggest. It can be concluded that $\mathrm{R}^{2}$ value links the short-circuit current and MPP current which leads to the evaluation of the PV module quality (losses in conductors between the PV cells, collecting electrodes, quality of the PV cell, etc.). The stronger the relation of MPP current and short-circuit current, the higher the $\mathrm{R}^{2}$ value i.e. the better linear dependency of MPP current and solar irradiance. HIT PV module Panasonic
VBHN240SE10 has the most positive MPP current slope of $0.09 \%$ per $\mathrm{W} / \mathrm{m}^{2}$ while $\mathrm{m}$-SiBisol BMO 250 and $\mathrm{p}$ SiBisol BMU 250 have the lowest slope of $0.06 \%$ per $\mathrm{W} / \mathrm{m}^{2}$.

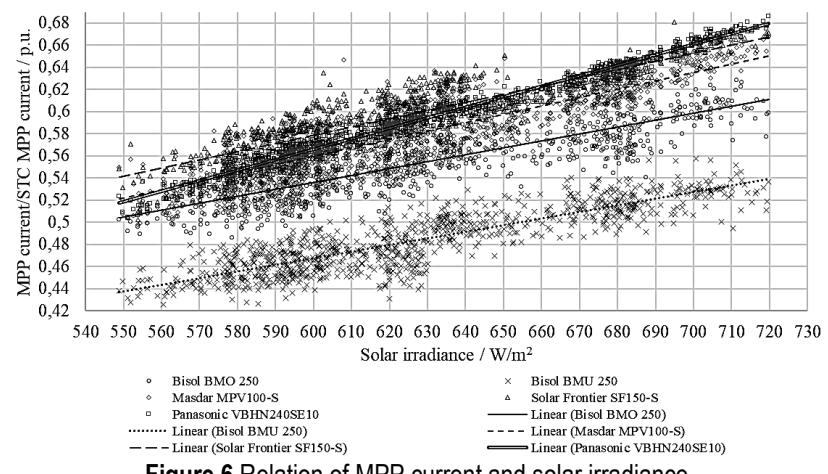

Figure 6 Relation of MPP current and solar irradiance

Table $4 R^{2}$ values of linear trend curves plotted for MPP current - solar

\begin{tabular}{|l|c|}
\multicolumn{2}{|c|}{ irradiance relation } \\
\hline \multicolumn{1}{|c|}{ PV module } & $R^{2} / \%$ \\
\hline Bisol BMO 250 & 73,69 \\
\hline Bisol BMU 250 & 75,09 \\
\hline Masdar MPV100S & 75,5 \\
\hline Solar Frontier SF150-S & 79,67 \\
\hline Panasonic VBHN240SE10 & 98,08 \\
\hline
\end{tabular}

Fig. 7 and Fig. 8 present dependencies of MPP voltage and efficiency on module temperatures, respectively, where MPP voltage and efficiency are normalized to the PV module STC values.
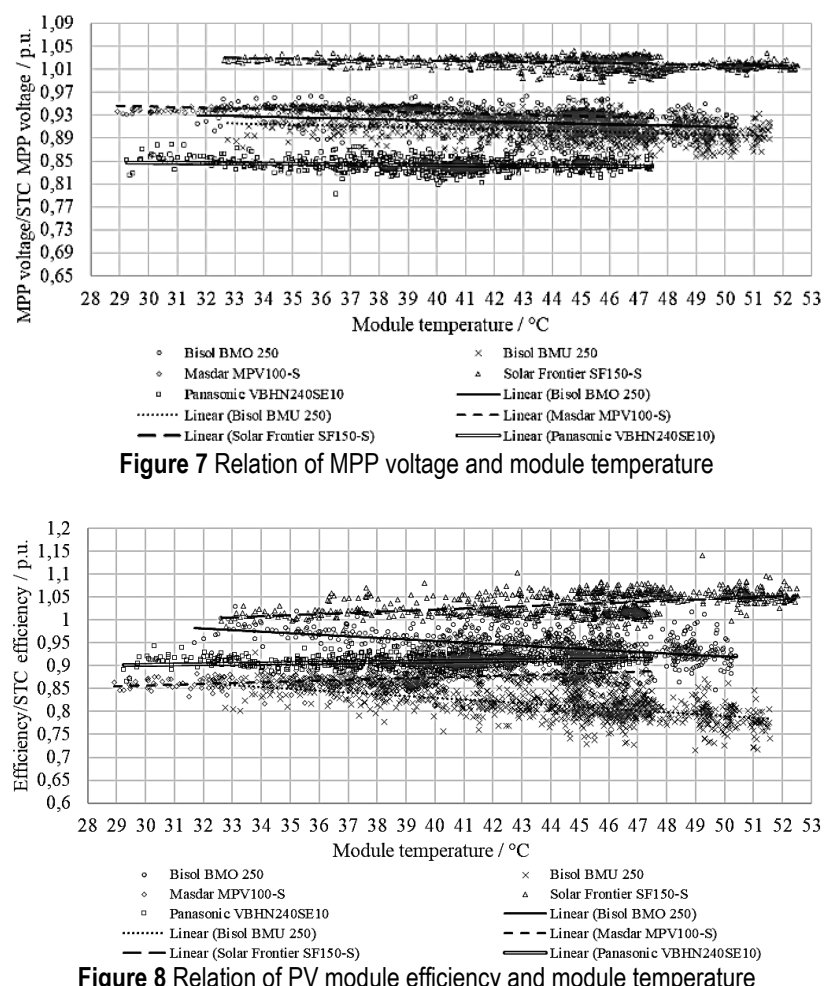

Fig. 7 indicates that MPP voltage is decreasing with module temperature increase. Observing the Eq. (5) [35], it can be concluded that efficiency of the PV module depends on the MPP voltage, MPP current and solar irradiance. Since the MPP voltage is in negative relation, which confirms Fig. 7, and MPP current is in positive relation to the module temperature (current temperature 
coefficient given by manufacturer) [34], it can be concluded that behaviour of the efficiency in relation to the module temperature presented in Fig. 8 depends on these two relations. If the MPP current increase is greater than MPP voltage decrease, efficiency will rise and vice-versa.

$\eta_{\mathrm{mod}}=\frac{P_{\mathrm{MPP}}}{G \cdot A}=\frac{U_{\mathrm{MPP}} \cdot I_{\mathrm{MPP}}}{G \cdot A}$

where: $\eta_{\text {mod }}-$ PV module efficiency, $U_{\mathrm{MPP}}-$ MPP voltage, $I_{\text {MPP }}-$ MPP current, $A-\mathrm{PV}$ module area, $G$-solar irradiance.

Fig. 7 and Fig. 8 also show that MPP voltage and efficiency of CIS PV module Solar Frontier SF150-S is higher than the STC values. This performance increase is a result of the light soaking effect which nearly every PV technology exhibits, although the value of these changes is differentiating from one PV technology to another [36]. Performance increase of CIS due to the light soaking effect is also stated in manufacturers specification of the PV module [31]. There are also other researches that studied the effect of light soaking on PV technologies [37]-[43].

The lowest normalized efficiency and the most negative efficiency slope occurs in $\mathrm{p}$-Si PV module Bisol BMU 250 which is expected due to the largest power temperature coefficient defined by the manufacturer ($0.4 \% /{ }^{\circ} \mathrm{C}$ )[29], as it will be elaborated in the following. Fig. 9 shows relation of measured output power of the PV module and solar irradiance where output power is normalized to the MPP output power of PV module at the STC. Results show linear dependence of PV module's output power on irradiance. Deviations from linear trendline occur due to higher module temperatures during the higher solar irradiances, in general.

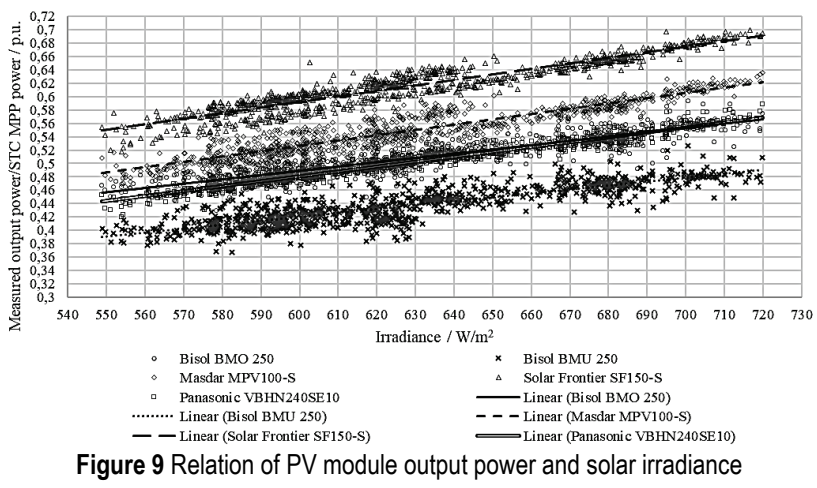

Fig. 10 presents dependency of the PV module efficiency on solar irradiance. According to Fig. 10, efficiency is decreasing with the irradiance increase as a result of the MPP voltage decreasing with module temperature increase (Fig. 7) while MPP current is increasing linearly to irradiance as seen in Fig. 6. This is a direct confirmation of the assumption of linear dependency of solar irradiance and MPP current as it was modelled in section 2.2.2 with the measurements obtained from data acquisition system in a real case study for European humid continental climate. This in turn also confirms the capacity evaluation method results obtained according to the IEC TS 61724-2 standard.

Tab. 5 gives comparison between results of the performance analysis according to the IEC TS 61724-2 standard i.e. PIP and average output power of PV module from filtered measured data (according to the IEC TS 61724-2 standard). Average output power of PV module is normalized to the STC nominal output power. As expected, normalized measured output power of the PV module corelates with $P I P$ i.e. result of capacity evaluation method according to the IEC TS 61724-2 standard. The difference lays in predicted target and measured values from the mathematical model used for calculation of the PIP.

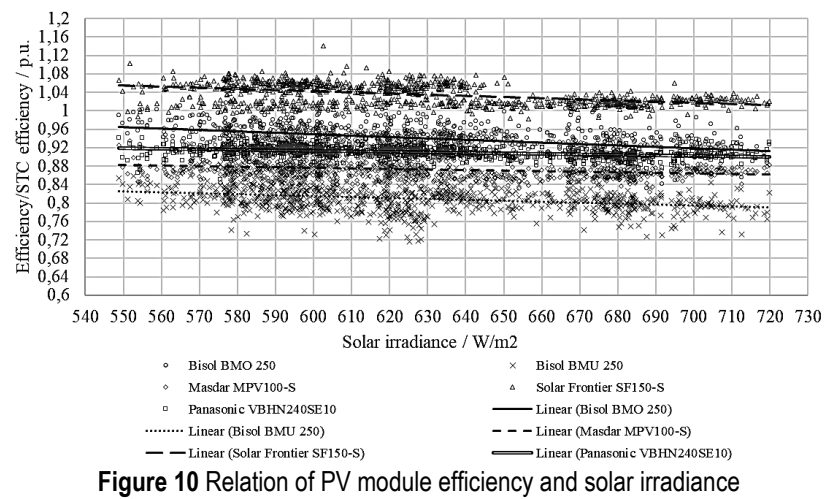

Table 5 Comparison of PIP and average output power of PV modules

\begin{tabular}{|l|c|c|}
\hline \multicolumn{1}{|c|}{ PV module } & $P I P / \%$ & $\begin{array}{c}\text { Average } P_{\text {meas }} / \\
\text { STC } P_{\text {MPP }} / \text { p.u. }\end{array}$ \\
\hline Bisol BMO 250 & 86,63 & 0,51 \\
\hline Bisol BMU 250 & 75,7 & 0,44 \\
\hline Masdar MPV100S & 90,06 & 0,55 \\
\hline Solar Frontier SF150-S & 102,77 & 0,61 \\
\hline Panasonic VBHN240SE10 & 83,64 & 0,5 \\
\hline
\end{tabular}

Furthermore, empirical mathematical model of efficiency depending on module temperature for every PV module is derived from the trend curves in Fig. 8. Empirical mathematical model form is given in (6) as:

$\eta_{\text {mod }}=\eta_{\text {mod, STC }}\left[b+m \cdot\left(T_{\text {mod }}-25\right)\right]$

where: $\eta_{\text {mod }}$ - PV module efficiency, $\eta_{\text {mod, sTC }}-$ nominal PV module efficiency at the STC, $b$ - intercept, $m-$ efficiency temperature coefficient, $T_{\bmod }-$ module temperature.

Tab. 6 gives coefficients $b$ and $m$ and equation of the efficiency empirical mathematical model for each PV module. Coefficients of empirical mathematical model given in Tab. 6 for the m-Si Bisol BMO 250 and p-Si Bisol BMU $250 \mathrm{PV}$ modules indicate that the efficiency is decreasing with the module temperature increase (negative $m$ coefficient). This behavior of $\mathrm{m}-\mathrm{Si}$ and $\mathrm{p}$-Si PV modules is also confirmed in [44], as it can be seen also in Fig. 11. Fig. 11 presents the normalized efficiency to the STC efficiency and module temperature of the studied $\mathrm{m}-\mathrm{Si}$ and p-Si PV modules on October 1, 2017. It is visible from Fig. 11 that efficiency drop occurs during higher module temperatures.

Coefficient $b$ for the a-Si, CIS and HIT PV modules indicates that efficiency is increasing with module temperature. This claim is confirmed with Fig. 12 which shows relation of efficiency normalized to the STC efficiency and module temperature of a-Si, CIS and HIT PV modules on October 1, 2017. It is visible from Fig. 12 that efficiencies do not experience drop even though the 
module temperature is rising during the day. In opposite, efficiency has an increasing tendency during the day. Deviations from the smooth efficiency curve in Fig. 11 and Fig. 12 are caused by the imperfection of inverter MPP tracker which does not keep operating point of the PV module in the MPP. Although new conclusions were drawn in this paper based on a real case empirical analysis of measurements, it should be taken into account that this study uses measurements for only 5 days in a year, therefore all results need to be additionally confirmed with long-term measurements.

Table 6 Empirical mathematical model and coefficients of efficiency for each PV module

\begin{tabular}{|l|c|c|c|}
\hline \multicolumn{1}{|c|}{ PV module } & $b / \mathrm{p} . \mathrm{u}$. & $\mathrm{m} / 1 /{ }^{\circ} \mathrm{C}$ & Equation \\
\hline Bisol BMO 250 & 1,0901 & $-0,0034$ & $\eta_{\mathrm{m}-\mathrm{Si}}=15,3 \cdot\left[1,0901-0,0034 \cdot\left(T_{\bmod }-25\right)\right]$ \\
\hline Bisol BMU 250 & 0,9865 & $-0,0039$ & $\eta_{\mathrm{p}-\mathrm{Si}}=15,3 \cdot\left[0,9865-0,0039 \cdot\left(T_{\bmod }-25\right)\right]$ \\
\hline Masdar MPV100-S & 0,8033 & $+0,0018$ & $\eta_{\mathrm{p}-\mathrm{Si}}=7 \cdot\left[0,8033-0,0018 \cdot\left(T_{\bmod }-25\right)\right]$ \\
\hline Solar Frontier SF150-S & 0,9262 & $+0,0024$ & $\eta_{\mathrm{p}-\mathrm{Si}}=12,2 \cdot\left[0,9262+0,0024 \cdot\left(T_{\bmod }-25\right)\right]$ \\
\hline Panasonic VBHN240SE10 & 0,8799 & $+0,0008$ & $\eta_{\mathrm{p}-\mathrm{Si}}=19 \cdot\left[0,8799+0,0008 \cdot\left(T_{\bmod }-25\right)\right]$ \\
\hline
\end{tabular}

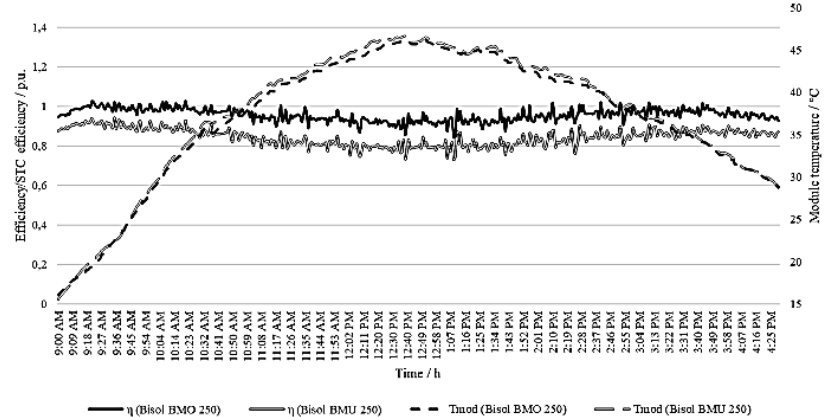

Figure 11 Efficiency and module temperature of $\mathrm{m}$-Si and $\mathrm{p}$-Si PV modules on October 1, 2017

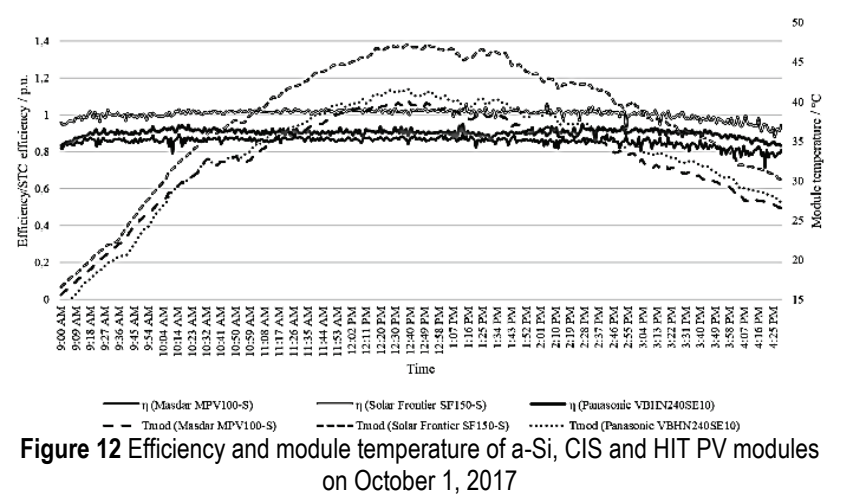

\section{CONCLUSION}

In this paper, performance of $5 \mathrm{PV}$ modules made of different technologies is analyzed. Studied PV modules are m-Si Bisol BMO 250, p-Si Bisol BMU 250, a-Si Masdar MPV100-S, CIS Solar Frontier SF150-S and HIT Panasonic VBHN240SE10. Analysis is conducted according to the short-term capacity evaluation method of PV's prescribed by IEC TS 61724-2 standard for 5 relatively sunny days in October 2017 (autumn). Measurements are obtained from measurement data acquisition system developed by Laboratory for Renewable Energy Sources at the FERIT Osijek.

Results of the capacity evaluation method indicate that CIS PV module Solar Frontier SF150-S has the greatest performance according to the IEC TS 61724-2 standard, therefore it is the most suitable PV module for the European humid continental climate conditions at microlocation of FERIT Osijek, Croatia. On the opposite, p-Si PV module Bisol BMU 250 PV has the lowest performance of all studied PV modules. Results obtained by analysis are also evaluated empirically using measured data. Performance analysis of studied PV modules is demonstrated trough dependencies of different parameters such as MPP voltage, current and power, module and ambient temperature, solar irradiance and efficiency. Charts show linear dependency for MPP current - solar irradiance, PV module efficiency - solar irradiance, MPP voltage - module temperature, PV module efficiency module temperature and PV module's output power irradiance relations. Furthermore, module temperature exhibits, in general, proportional dependency on irradiance but it is also influenced by duration of previous cumulative exposure to the Sun radiation (irradiation) and different ambient temperatures, which therefore results in the different module temperatures even at the same irradiances.

General conclusion is that empirical evaluation confirms the assumption of linear dependency of solar irradiance and MPP current used in mathematical model since efficiency is decreasing with the irradiance increase as a result of the MPP voltage decreasing with module temperature increase. This is a direct measurement confirmation of the used capacity evaluation method according to the IEC TS 61724-2 standard.

Based on measurements, an empirical mathematical model of efficiency depending on module temperature is derived for each PV module. Results indicate that efficiency of m-Si Bisol BMO 250 and p-Si Bisol BMU $250 \mathrm{PV}$ modules is decreasing with module temperature increase while efficiency of a-Si Masdar MPV100-S, CIS Solar Frontier SF150-S and HIT Panasonic VBHN240SE10 PV modules is increasing with module temperature.

Further research will focus on long-term energy evaluation method of performance analysis according to the IEC TS 61724-3 standard for 5 PV modules made of different technologies.

\section{REFERENCES}

[1] European Commission. (2014). 2030 climate \& energy framework. Retrieved December 18, 2017, from https://ec.europa.eu/energy/en/topics/energy-strategy-and -energy-union/2030-energy-strategy

[2] Arnulf, J.-W. (2016). PV Status Report 2016. Retrieved from http://publications.jrc.ec.europa.eu/repository/ bitstream/JRC103426/ldna28159enn.pdf.

[3] REN21. (2018). Renewables 2018 Global Status Report. Paris, France: REN21 Secretariat.

[4] Cañete, C., Carretero, J., \& Sidrach-de-Cardona, M. (2014). Energy performance of different photovoltaic module technologies under outdoor conditions. Energy, 65(April), 
295-302. https://doi.org/10.1016/j.energy.2013.12.013

[5] Sharma, V., Kumar, A., Sastry, O. S., \& Chandel, S. S. (2013). Performance assessment of different solar photovoltaic technologies under similar outdoor conditions. Energy, 58, 511-518. https://doi.org/10.1016/j.energy.2013.05.068

[6] Ali, M. Al \& Emziane, M. (2013). Performance Analysis of Rooftop PV Systems in Abu Dhabi. Energy Procedia, 42, 689-697. https://doi.org/10.1016/j.egypro.2013.11.071

[7] Muñoz, Y., Zafra, D., Acevedo, V., \& Ospino, A. (2014). Analysis of energy production with different photovoltaic technologies in the Colombian geography. IOP Conference Series: Materials Science and Engineering, 59(1), 1-9. https://doi.org/10.1088/1757-899X/59/1/012012

[8] Elibol, E., Özmen, Ö. T., Tutkun, N., \& Köysal, O. (2017). Outdoor performance analysis of different PV panel types. Renewable and Sustainable Energy Reviews, 67, 651-661. https://doi.org/10.1016/..rser.2016.09.051

[9] Tossa, A. K., Soro, Y. M., Thiaw, L., Azoumah, Y., Sicot, L., Yamegueu, D., ... Razongles, G. (2016). Energy performance of different silicon photovoltaic technologies under hot and harsh climate. Energy, 103, 261-270. https://doi.org/10.1016/j.energy.2016.02.133

[10] Guenounou, A., Malek, A., \& Aillerie, M. (2016). Comparative performance of PV panels of different technologies over one year of exposure: Application to a coastal Mediterranean region of Algeria. Energy Conversion and Management, 114, 356-363. https://doi.org/10.1016/j.enconman.2016.02.044

[11] Balaska, A., Tahri, A., Tahri, F., \& Stambouli, A. B. (2017) Performance assessment of five different photovoltaic module technologies under outdoor conditions in Algeria. Renewable Energy, 107, 53-60. https://doi.org/10.1016/i.renene.2017.01.057

[12] Ferrada, P., Araya, F., Marzo, A., \& Fuentealba, E. (2015). Performance analysis of photovoltaic systems of two different technologies in a coastal desert climate zone of Chile. Solar Energy, 114, 356-363. https://doi.org/10.1016/j.solener.2015.02.009

[13] Başoğlu, M. E., Kazdaloğlu, A., Erfidan, T., Bilgin, M. Z., \& Cakır, B. (2015). Performance analyzes of different photovoltaic module technologies under İzmit, Kocaeli climatic conditions. Renewable and Sustainable Energy Reviews, 52, 357-365. https://doi.org/10.1016/..rser.2015.07.108

[14] Savvakis, N. \& Tsoutsos, T. (2015). Performance assessment of a thin film photovoltaic system under actual Mediterranean climate conditions in the island of Crete. Energy, 90, 1435-1455. https://doi.org/10.1016/j.energy.2015.06.098

[15] Fuentealba, E., Ferrada, P., Araya, F., Marzo, A., Parrado, C., \& Portillo, C. (2015). Photovoltaic performance and LCoE comparison at the coastal zone of the Atacama Desert, Chile. Energy Conversion and Management, 95, 181-186. https://doi.org/10.1016/j.enconman.2015.02.036

[16] Limmanee, A., Udomdachanut, N., Songtrai, S., Kaewniyompanit, S., Sato, Y., Nakaishi, M., ... Sakamoto, Y. (2015). Seasonal variations in performance loss of photovoltaic modules: A case study in Thailand Science Park. Journal of Renewable and Sustainable Energy, 7(5), 111. https://doi.org/10.1063/1.4934677

[17] Guerra, T. A., Guerra, J. A., Tabernero, B. O., \& De La Cruz García, G. (2017). Comparative energy performance analysis of six primary photovoltaic technologies in Madrid (Spain). Energies, 10(6), 1-23. https://doi.org/10.3390/en10060772

[18] Malvoni, M., Leggieri, A., Maggiotto, G., Congedo, P. M., \& De Giorgi, M. G. (2017). Long term performance, losses and efficiency analysis of a $960 \mathrm{kWp}$ photovoltaic system in the Mediterranean climate. Energy Conversion and Management, 145, 169-181. https://doi.org/10.1016/j.enconman.2017.04.075
[19] Phinikarides, A., Makrides, G., Zinsser, B., Schubert, M., \& Georghiou, G. E. (2015). Analysis of photovoltaic system performance time series: Seasonality and performance loss. Renewable Energy, 77, 51-63. https://doi.org/10.1016/j.renene.2014.11.091

[20] Seme, S., Krawczyk, A., Tondyra, E. Ł., Štumberger, B., \& Hadžiselimović, M. (2017). The efficiency of different orientations of photovoltaic systems. Przeglad Elektrotechniczny, (1), 203-206. https://doi.org/10.15199/48.2017.01.49

[21] Seme, S., Požun, J., Štumberger, B., \& Hadžiselimovic, M. (2015). Energy Production of Different Types and Orientations of Photovoltaic Systems Under Outdoor Conditions. Journal of Solar Energy Engineering, 137(2), 110. https://doi.org/10.1115/1.4029736

[22] Sredenšek, K., Šlamberger, J., Štumberger, B., Hadžiselimović, M., \& Seme, S. (2017). Monitoring of the solar power plants and performance ratio (Vol. 050009, pp. 1-6). https://doi.org/10.1063/1.4994533

[23] IEC. (2016c). IEC TS 61724-3 Photovoltaic system performance - Part 3: Energy evaluation method. IEC.

[24] IEC. (2016b). IEC TS 61724-2 Photovoltaic system performance - Part 2: Capacity Evaluation Method. IEC

[25] Meteorological and hydrological institute of Croatia. (2017). Climate in Croatia. Retrieved January 30, 2018, from http://klima.hr/klima.php?id=k1\#pog1

[26] IEC. (2016a). IEC TS 61724-1 Photovoltaic system performance - Part 1: Monitoring.

[27] Faculty of Electrical Engineering Computer Science and Information Technology Osijek. (2018). Laboratory for Renewable Energy Sources. Retrieved October 13, 2018, from http://reslab.ferit.hr/

[28] BISOL Group d.o.o. (2014a). BISOL BMO 250 datasheet. Retrieved from https://www.zonnepanelen.net/nl/pdf/ panels/BISOL_Premium_BMO_NL.pdf

[29] BISOL Group d.o.o. (2014b). BISOL BMU 250 datasheet. Retrieved from http://www.oksolar.it/Certificazioni/ datasheet-bisol-premium-BMU-245-265_IT_dec2014.pdf

[30] Masdar PV GmbH. (2010). Masdar MP $\bar{P} \overline{100-S}$ datasheet. Retrieved from http://www.secondsol.de/index.php? page $=$ ad showup \&ID AD UPLOAD $=2264$

[31] Solar Frontier Europe GmbH. (2012). Solar Frontier SF150$S$ datasheet. Retrieved from https://www.solar-frontier.eu/ fileadmin/content/downloads/modules/en/20141030/produc t-overview-s-series-english.pdf

[32] SANYO Component Europe GmbH. (2012). Panasonic VBHN240SE10 datasheet. Retrieved from $\mathrm{http} / / /$ de.krannich-solar.com/fileadmin/content/data sheets/ solar_modules/Panasonic_N235-240_VBHN2xxSE10_EN .pdf

[33] Barukčić, M., Hederić, Ž., Hadžiselimović, M., \& Seme, S. (2018). A simple stochastic method for modelling the uncertainty of photovoltaic power production based on measured data. Energy, 165, 246-256. https://doi.org/10.1016/j.energy.2018.09.134

[34] Masters, G. M. (2004). Renewable and Efficient Electric Power Systems. Hoboken, NJ, USA: John Wiley \& Sons, Inc. https://doi.org/10.1002/0471668826

[35] Häberlin, H. (2012). Photovoltaics. Chichester, UK: John Wiley \& Sons, Ltd. https://doi.org/10.1002/9781119976998

[36] Gostein, M., \& Dunn, L. (2011). Light Soaking Effects on PV Modules: Overview and Literature Review. NREL PV Module Reliability Workshop, (February), 1-25. https://doi.org/10.1109/PVSC.2011.6186605

[37] Schujman, S. B., Mann, J. R., Hull, C., Conteh, A., Dufresne, G., Laque, L. M., ... Haldar, P. (2014). Effects of lightsoaking and temperature on different PV technologies. In 2014 IEEE 40th Photovoltaic Specialist Conference, PVSC 2014 (pp. 2626-2629). https://doi.org/10.1109/PVSC.2014.6925468 
[38] Willett, D. \& Kuriyagawa, S. (1993). The effects of sweep rate, voltage bias and light soaking on the measurement of CIS-based solar cell characteristics. In Conference Record of the Twenty Third IEEE Photovoltaic Specialists Conference - 1993 (Cat. No. 93CH3283-9) (pp. 495-500). https://doi.org/10.1109/PVSC.1993.347131

[39] Sasala, R. A. \& Sites, J. R. (1993). Time dependent voltage in CuInSe2 and CdTe solar cells. In Conference Record of the IEEE Photovoltaic Specialists Conference (pp. 543-568). https://doi.org/10.1109/PVSC.1993.347036

[40] Kenny, R. P., Nikolaeva-Dimitrova, M., \& Dunlop, E. D. (2007). Performance measurements of CIS modules: Outdoor and pulsed simulator comparison for power and energy rating. In Conference Record of the 2006 IEEE 4th World Conference on Photovoltaic Energy Conversion, WCPEC-4 (Vol. 2, pp. 2058-2061). https://doi.org/10.1109/WCPEC.2006.279907

[41] Kuurne, J., Tolvanen, A., \& Hyvarinen, J. (2008). Sweep time, spectral mismatch and light soaking in thin film module measurement. In Conference Record of the IEEE Photovoltaic Specialists Conference (pp. 7-9). https://doi.org/10.1109/PVSC.2008.4922583

[42] Boulhidja, S., \& Mellit, A. (2016). Performance degradation of CIGS photovoltaic modules by light soaking and reverse bias. In 2015 4th International Conference on Electrical Engineering, ICEE 2015 (pp. 1-4). https://doi.org/10.1109/INTEE.2015.7416720

[43] Ishii, T., Otani, K., Takashima, T., \& Ikeda, K. (2014). Change in $I-V$ characteristics of thin-film photovoltaic (PV) modules induced by light soaking and thermal annealing effects. Progress in Photovoltaics: Research and Applications, 22(9), 949-957. https://doi.org/10.1002/pip.2346

[44] Skoplaki, E. \& Palyvos, J. A. (2009). On the temperature dependence of photovoltaic module electrical performance: A review of efficiency/power correlations. Solar Energy, 83(5), 614-624. https://doi.org/10.1016/j.solener.2008.10.008

\section{Contact information:}

Matej ŽNIDAREC, MSc

(Corresponding author)

J. J. Strossmayer University of Osijek,

Faculty of Electrical Engineering, Computer Science and Information

Technology Osijek,

Kneza Trpimira 2B, 31000 Osijek, Croatia

matej.znidarec@ferit.hr

Damir ŠLJIVAC, PhD, Full Professor

J. J. Strossmayer University of Osijek

Faculty of Electrical Engineering, Computer Science and Information

Technology Osijek,

Kneza Trpimira 2B, 31000 Osijek, Croatia

damir.sljivac@ferit.hr

Dario DOŠEN, MSc

J. J. Strossmayer University of Osijek,

Faculty of Electrical Engineering, Computer Science and Information

Technology Osijek,

Kneza Trpimira 2B, 31000 Osijek, Croatia

dario.dosen@ferit.hr 